\title{
COMPARISON OF PREOPERATIVE AND POSTOPERATIVE ASTIGMATISM FOLLOWING PTERYGIUM EXCISION WITH CONJUNCTIVAL AUTOGRAFT
}

\author{
Ashish Goyal1, Chetanya Prakash Gupta², Daya Chand Gupta ${ }^{3}$ \\ ${ }_{1}^{1}$ Resident, Department of Ophthalmology, Mahatma Gandhi Medical College and Hospital, Jaipur, Rajasthan, India. \\ ${ }^{2}$ Associate Professor, Department of Ophthalmology, Mahatma Gandhi Medical College and Hospital, Jaipur, Rajasthan, India. \\ 3Professor, Department of Ophthalmology, Mahatma Gandhi Medical College and Hospital, Jaipur, Rajasthan, India.
}

\section{ABSTRACT}

\section{BACKGROUND}

Pterygium is a common ocular surface disorder characterised by triangular fibrovascular subepithelial ingrowth of degenerative bulbar conjunctival tissue over the limbus onto the cornea in the interpalpebral area. It is usually present only on the nasal side. It can cause astigmatism by distorting the corneal topography and can also obscure the optical centre of the cornea in advanced cases. Excision of pterygium leads to statistically significant reduction in astigmatism, which improves vision significantly.

Aims and Objectives-

1. To correlate the degree of pterygium-induced astigmatism with pterygium size.

2. To analyse the change in pterygium-induced astigmatism after its excision and autograft placement.

\section{MATERIALS AND METHODS}

This was a prospective observational study of 50 patients with primary nasal pterygium who underwent pterygium excision surgery with conjunctival autografting at Department of Ophthalmology, Mahatma Gandhi Medical College and Hospital, Sitapura, Jaipur from March 2017 to February 2018. Pterygium was graded into Grade I, II, III and IV according to its size and pre-operative keratometry readings were compared with findings on day 1, 1 week, 1 month and 3 months post-operatively. The data was compared using student's paired t-test.

\section{RESULTS}

As the grade of pterygium increased, the mean value of astigmatism caused by it also increased from $1.44 \pm 0.66 \mathrm{D}$ in Grade $\mathrm{I}$, $2.50 \pm 1.05$ in Grade II and $3.65 \pm 0.56$ in Grade III to $5.68 \pm 1.25$ D in Grade IV. The mean change of astigmatism was $1.40 \pm 0.26$ $(\mathrm{p}<0.0001)$ on 1 st post-op day, $1.98 \pm 0.24$ ( $\mathrm{p}<0.0001) 1$-week post-op, $2.54 \pm 0.24(\mathrm{p}<0.0001) 1$-month post-op and $2.58 \pm 0.24$ $(\mathrm{p}<0.0001) 3$ months post-operatively.

\section{CONCLUSION}

Astigmatism induced is directly proportional to the grade of pterygium. Pterygium excision surgery reduced the pterygiuminduced astigmatism significantly.

\section{KEY WORDS}

Pterygium, Astigmatism, Pterygium-Induced Astigmatism.

HOW TO CITE THIS ARTICLE: Goyal A, Gupta CP, Gupta DC. Comparison of preoperative and postoperative astigmatism following pterygium excision with conjunctival autograft. J. Evolution Med. Dent. Sci. 2018;7(29):3321-3324, DOI: $10.14260 /$ jemds $/ 2018 / 748$

\section{BACKGROUND}

Pterygium is characterised by triangular fibrovascular subepithelial ingrowth of degenerative bulbar conjunctival tissue over the limbus onto the cornea in the interpalpebral area.

It is typically seen in patients who have been living in hot and dry climates. It is widely accepted that ultraviolet light exposure is the most important causative factor in the pathogenesis of pterygium. It is usually present only on the nasal side, but is sometimes bilateral. Pterygium can cause astigmatism by distorting the corneal topography and can also obscure the optical center of the cornea in advanced cases.

'Financial or Other Competing Interest': None.

Submission 07-06-2018, Peer Review 29-06-2018,

Acceptance 07-07-2018, Published 16-07-2018.

Corresponding Author:

Dr. Ashish Goyal,

A-701, VT Apartment, VT Road,

Mansarover, Jaipur-302020, Rajasthan, India.

E-mail: ashishg88@gmail.com

DOI: $10.14260 /$ jemds $/ 2018 / 748$ include chronic ocular surface inflammation, tearing, astigmatism and blurred vision. There are several mechanisms that can explain the induced astigmatism. These include (a) pooling of the tear film at the leading edge of the pterygium and (b) mechanical traction exerted by the pterygium on cornea. A small pterygium not involving the visual axis can be managed medically. The only definitive treatment is surgical removal. Conjunctival Autografting- In this technique free graft from superior/ superotemporal bulbar conjunctiva with limbal stem cell transplantation is placed over the bare sclera after excision of a pterygium. It is now one of the procedures of choice for pterygium excision. Excision of pterygium leads to statistically significant reduction in astigmatism, which improves vision significantly. The objectives with which this study was carried out were to study the relationship of pre-operative size of pterygium with the astigmatism induced and change in it after surgery.

\section{MATERIALS AND METHODS}

This was a prospective observational study of 50 patients with primary nasal pterygium who underwent pterygium 
excision surgery with conjunctival autografting at Department of Ophthalmology, Mahatma Gandhi Medical College and Hospital, Sitapura, Jaipur. All the patients were in age group from 18 - 60 years, selected by non-probability convenient sampling method, of which 28 were males and 22 were females. The study period extended from March 2017 to February 2018.

\section{Inclusion Criteria}

Patients with primary nasal pterygium between 18 - 60 years of age.

\section{Exclusion Criteria}

- Patients with pseudopterygium, recurrent pterygium or bilateral pterygium.

- History of corneal infection or scarring.

- Glaucoma, trauma or any other ocular pathology.

- Past history of pterygium excision or any other eye surgery.

- History of any chronic systemic disease.

Written and informed consent was taken from all the patients at the time of inclusion in the study.

\section{Pterygium was Graded depending on the Extent of} Corneal Involvement-

- Grade I- crossing limbus.

- $\quad$ Grade II- midway between limbus and pupil.

- Grade III- reaching up to pupillary margin.

- Grade IV- crossing pupillary margin.

Autokeratometer was used to determine the astigmatism. The patients were re-examined on 1 st post-op day, 1 week, 1 month and 3 months post-operatively. The data was compared using student's paired t-test.

\section{RESULTS}

\begin{tabular}{|c|c|c|c|}
\hline Age Groups (Years) & Male & Female & Total \\
\hline $18-30$ & $6(21.42 \%)$ & $7(31.18 \%)$ & $13(26 \%)$ \\
\hline $31-40$ & $8(28.57 \%)$ & $9(40.90 \%)$ & $17(34 \%)$ \\
\hline $41-50$ & $9(32.14 \%)$ & $3(13.63 \%)$ & $12(24 \%)$ \\
\hline $51-60$ & $5(17.85 \%)$ & $3(13.63 \%)$ & $8(16 \%)$ \\
\hline Total & $\mathbf{2 8 ( 5 6 \% )}$ & $\mathbf{2 2 ( 4 4 \% )}$ & $\mathbf{5 0 ( 1 0 0 \% )}$ \\
\hline Mean \pm SD & $40.50 \pm 11.32$ & $36.23 \pm 11.93$ & $38.62 \pm 11.67$ \\
\hline Table 1. Age and Gender Wise distribution of Cases \\
\hline
\end{tabular}

The above table depicts that $28(56 \%)$ cases were male and $22(44 \%)$ cases were female. Maximum cases were in the age group of 31 - 50 years $(29,58 \%)$.

\begin{tabular}{|c|c|c|}
\hline Pterygium & Number & Percentage \\
\hline Grade I & 4 & $8 \%$ \\
\hline Grade II & 21 & $42 \%$ \\
\hline Grade III & 15 & $30 \%$ \\
\hline Grade IV & 10 & $20 \%$ \\
\hline Total & $\mathbf{5 0}$ & $\mathbf{1 0 0} \%$ \\
\hline \multicolumn{2}{|c|}{ Table 2. Shows the Grade of Pterygium }
\end{tabular}

The above table depicts that most of the cases had Grade II and Grade III pterygium (36, 72\%).

\begin{tabular}{|r|c|c|c|c|}
\hline & Grade I & Grade II & Grade III & Grade IV \\
\hline Mean \pm SD & $1.438 \pm 0.657$ & $2.50 \pm 1.052$ & $3.650 \pm 0.559$ & $5.675 \pm 1.247$ \\
\hline Table 3. Mean Value of Astigmatism Pre-Operatively \\
\hline
\end{tabular}

The above table depicts that as the grade of pterygium increased, the mean value of astigmatism caused by it also increased from $1.44 \pm 0.66 \mathrm{D}$ in Grade I to $5.68 \pm 1.25 \mathrm{D}$ in Grade IV.

\begin{tabular}{|c|c|c|c|c|}
\hline & At 1 ${ }^{\text {st Day }}$ & At 1 Week & $\begin{array}{c}\text { At 1 } \\
\text { Month }\end{array}$ & $\begin{array}{c}\text { At 3 } \\
\text { Months }\end{array}$ \\
\hline Mean \pm SD & $0.250 \pm 0.43$ & $0.5 \pm 0.417$ & $1.0 \pm 0.349$ & $1.0 \pm 0.349$ \\
\hline P-value & 0.5821 & 0.276 & 0.0289 & 0.0289 \\
\hline Significance & $\begin{array}{c}\text { Non- } \\
\text { significant }\end{array}$ & $\begin{array}{c}\text { Non- } \\
\text { significant }\end{array}$ & Significant & Significant \\
\hline $\begin{array}{c}\text { Table 4. Mean Change of Astigmatism from pre-operative } \\
\text { to various intervals in Grade I Pterygium }\end{array}$ \\
\hline
\end{tabular}

The above table depicts that the change of mean value of astigmatism in Grade I pterygium was not significant when compared pre-op to $1^{\text {st }}$ day and after 1 week. The change was found significant 1 month and 3 months post-operatively.

\begin{tabular}{|c|c|c|c|c|}
\hline & At 1st Day & At 1 Week & $\begin{array}{c}\text { At 1 } \\
\text { Month }\end{array}$ & $\begin{array}{c}\text { At 3 } \\
\text { Months }\end{array}$ \\
\hline Mean \pm SD & $0.869 \pm 0.265$ & $1.214 \pm 0.251$ & $1.75 \pm 0.349$ & $1.77 \pm 0.238$ \\
\hline P-value & 0.0022 & $<0.0001$ & $<0.0001$ & $<0.0001$ \\
\hline Significance & Significant & Significant & Significant & Significant \\
\hline $\begin{array}{r}\text { Table 5. Mean change of Astigmatism from pre-operative } \\
\text { to various intervals in Grade II Pterygium }\end{array}$ \\
\hline
\end{tabular}

The above table depicts that the change of mean value of astigmatism in Grade II pterygium was highly significant when compared pre-op to $1^{\text {st }}$ day, after 1 week, 1 month and 3 months post-operatively.

\begin{tabular}{|c|c|c|c|c|}
\hline & At 1st Day & At 1 Week & At 1 Month & At 3 Months \\
\hline Mean \pm SD & $1.667 \pm 0.79$ & $2.417 \pm 0.17$ & $2.883 \pm 0.160$ & $2.993 \pm 0.613$ \\
\hline P-value & $<0.0001$ & $<0.0001$ & $<0.0001$ & $<0.0001$ \\
\hline Significance & Significant & Significant & Significant & Significant \\
\hline $\begin{array}{c}\text { Table 6. Mean Change of Astigmatism from pre-operative } \\
\text { to various intervals in Grade III Pterygium }\end{array}$ \\
\hline
\end{tabular}

The above table depicts that the change of mean value of astigmatism in Grade III pterygium was highly significant $\left(p<0.0001\right.$ each) when compared pre-op to $1^{\text {st }}$ day, after 1 week, 1 month and 3 months post-operatively.

\begin{tabular}{|c|c|c|c|c|}
\hline & At 1 ${ }^{\text {st }}$ Day & At 1 Week & At 1 Month & $\begin{array}{c}\text { At 3 } \\
\text { Months }\end{array}$ \\
\hline Mean \pm SD & $2.550 \pm 0.504$ & $3.550 \pm 0.476$ & $4.30 \pm 0.467$ & $4.35 \pm 0.473$ \\
\hline P-value & $<0.0001$ & $<0.0001$ & $<0.0001$ & $<0.0001$ \\
\hline Significance & Significant & Significant & Significant & Significant \\
\hline
\end{tabular}

Table 7. Mean Change of Astigmatism from pre-operative to various intervals in Grade IV Pterygium

The above table depicts that the change of mean value of astigmatism in Grade IV pterygium was highly significant ( $p<0.0001$ each) when compared pre-op to $1^{\text {st }}$ day, after 1 week, 1 month and 3 months post-operatively. 


\begin{tabular}{|c|c|c|c|c|}
\hline & At 1 ${ }^{\text {st }}$ Day & At 1 Week & At 1 Month & $\begin{array}{c}\text { At 3 } \\
\text { Months }\end{array}$ \\
\hline Mean \pm SD & $1.395 \pm 0.2$ & $1.985 \pm 0.24$ & $2.540 \pm 0.23$ & $2.575 \pm 0.23$ \\
& 600 & 49 & 84 & 87 \\
\hline P-value & $<0.0001$ & $<0.0001$ & $<0.0001$ & $<0.0001$ \\
\hline Significance & Significant & Significant & Significant & Significant \\
\hline
\end{tabular}

Table 8. Mean Change of Astigmatism from pre-operative to various Intervals

The above table depicts that the changes of mean value of astigmatism were highly significant $(\mathrm{p}<0.0001$ each) when compared pre-operatively to $1^{\text {st }}$ day, after 1 week, 1 month and 3 months post-operatively $(1.40 \pm 0.26,1.99 \pm 0.25$, $2.54 \pm 0.24$ and $2.58 \pm 0.24$ respectively).

\section{DISCUSSION}

Pterygium induced astigmatism is a cause of gradual diminution of vision. Traction generated mechanically and changes in the tear film are the causes of change in corneal curvature. These cases were operated for pterygium excision with conjunctival autograft and changes in corneal curvature and astigmatism corrected by pterygium surgery was noted on different post-operative days. The astigmatism seen in the patients with pterygium represents both naturally occurring astigmatism and induced astigmatism. It may be incorrect to label the entire astigmatism as induced. Pterygium was found to be most common between $31-40$ years of age group (34\%). $26 \%$ cases were between the age group of $18-30$ years and $24 \%$ were in the age group of $41-50$ years. The increased incidence in these age groups was probably because they were more exposed to sun, dust and hot climate due to their more outdoor work. The mean age of patients in our study was 38.62 years. This finding correlates with the study by Hashemi et al (2017), ${ }^{1}$ who found the mean age of patients with pterygium to be 37.30 years. In our study, pterygium was found to be most common between $31-40$ years of age group (34\%). This finding is in accordance with study by Marmamula et al (2013), ${ }^{2}$ who in their study found the most common age group to be $30-39$ years (33.30\%). Also, Anbesse et al (2017) ${ }^{3}$ in their study found the most common age group presenting with pterygium to be of 20 40 years. In our study, $56 \%$ of the cases were male and $44 \%$ were female. This is in accordance with the observation of Duke Elder (1965) ${ }^{4}$, Youngson (1972) ${ }^{5}$ and R Rachmiel (1995). ${ }^{6}$ All of them have reported male predominance in their studies. In our study, Grade II and III pterygium were encountered in $72 \%$ of the cases. $8 \%$ cases of Grade I and $20 \%$ cases of Grade IV pterygium were seen. This observation was also seen by Maheshwari $(2003)^{7}$ and Shelke et al $(2014)^{8}$ in which maximum number of patients were of Grade II and III type pterygium (78\% and 89\% respectively). In our study, mean astigmatism induced by Grade I pterygium was found to be $1.44 \mathrm{D}$, by Grade II 2.50 D, by Grade III 3.65 D and by Grade IV 5.68 D. Comparing the corneal astigmatism amongst the various grades of pterygium, a statistically significant increase in astigmatism was noted with the increase in the Grade from I to IV. Rana Altan Yaycioglu et al (2013) ${ }^{9}$ also concluded that as the size of pterygium increases the pre-operative astigmatism increases. These results also correlate with the studies done by Fong et al (1998), ${ }^{10}$ Alison L and George AS (1998), ${ }^{11}$ Avisar et al (2000), ${ }^{12}$ Maheshwari (2003) ${ }^{7}$ and Popat et al (2014) ${ }^{13}$ who co-related the degree of pterygium induced astigmatism with its size. In our study, the mean change of astigmatism in Grade I pterygium was not significant on the $1^{\text {st }}$ post-op day and on 1-week follow-up visit. However, at 1 month and 3 months follow-up visits, this change was found significant. In Grade II, III and IV pterygium, the mean change of astigmatism from pre-operative to 1 month follow-up visit was found to be $1.75 \mathrm{D}, 2.88 \mathrm{D}$ and $4.30 \mathrm{D}$ respectively. Popat et al (2014) ${ }^{13}$ found that pterygium excision leads to significant decrease in astigmatism and that this decrease was related to the size of the pterygium. Fong et al (1998), ${ }^{10}$ Avisar et al (2000) ${ }^{12}$ and Maheshwari (2003) ${ }^{7}$ also made similar observations. There was little difference in the change in astigmatism from 1 month to 3 months post-operative period. Considering all the cases together the mean astigmatism pre-operatively was $3.40 \mathrm{D}$ which got reduced to $2.00 \mathrm{D}$ at first post-op day, $1.41 \mathrm{D}$ after 1 week, $0.86 \mathrm{D}$ after 1 month and $0.82 \mathrm{D} 3$ months post-operatively. The refractive components were demonstrated to stabilise at 1 month following pterygium surgery in our study, which is consistent with study done by Tomidokoro A et al (2000) ${ }^{14}$ and Popat et al (2014),13 in which the refractive components were demonstrated to stabilise at 1.5 months following pterygium surgery.

These observations clearly indicate that pterygium induced astigmatism increases with increasing size of pterygium and its excision significantly reduces the astigmatism.

\section{CONCLUSION}

This study showed that as the size of pterygium increases, the amount of induced astigmatism also increases. The present study also showed that successful pterygium excision surgery reduces the pterygium induced astigmatism.

\section{REFERENCES}

[1] Hashemi H, Khabazkhoob M, Yekta A, et al. The prevalence and determinants of pterygium in rural areas. J Curr Ophthalmol 2017;29(3):194-8.

[2] Marmamula S, Khanna RC, Rao GN. Population-based assessment of prevalence and risk factors for pterygium in the South Indian state of Andhra Pradesh: the Andhra Pradesh Eye Disease Study. Invest Ophthalmol Vis Sci 2013;54(8):5359-66.

[3] Anbesse DH, Kassa T, Kefyalew B, et al. Prevalence and associated factors of pterygium among adults living in Gondar city, Northwest Ethiopia. PLoS One 2017;12(3): e0174450.

[4] Duke Elder S. Diseases of the outer eye, in system of ophthalmology. Vol. 8. London: Henry Kimpton 1965.

[5] Youngson RM. Pterygium in Israel. Am J Ophthalmol 1972;74(5):954-9.

[6] Rachmiel R, Leiba H, Levartovsky S. Results of treatment with topical mitomycin $\mathrm{C} 0.02 \%$ following excision of primary pterygium. $\mathrm{Br} \mathrm{J}$ Ophthalmol 1995;79(3):233-6.

[7] Maheshwari S. Effect of pterygium excision on pterygium induced astigmatism. Indian J Ophthalmol 2003;51(2):187-8.

[8] Shelke E, Kawalkar U, Wankar R, et al. Effect of pterygium excision on pterygium induced astigmatism and visiual acuity. Int J Adv Health Sci 2014;1(8):1-3. 
[9] Altan-Yaycioglu R, Kucukerdonmez C, Karalezli A, et al. Astigmatic changes following pterygium removal: comparison of 5 different methods. Indian J Ophthalmol 2013;61(3):104-8.

[10] Fong KS, Balakrishnan V, Chee SP, et al. Refractive change following pterygium surgery. CLAO J 1998;24(2):115-7.

[11] Alison L, George AS. Correlation between pterygium size and induced corneal astigmatism. Cornea 1998;17(1):28-30.
[12] Avisar R, Loya N, Yassur Y, et al. Pterygium-induced corneal astigmatism. Isr Med Assoc J 2000;2(1):14-5.

[13] Popat KB, Sheth HK, Vyas VJ, et al. A study on changes in keratometry readings and astigmatism induced by pterygium before and after pterygium excision surgery. J Res Med Den Sci 2014;2(3):37-42.

[14] Tomidokoro A, Miyata K, Sakaguchi Y, et al. Effects of pterygium on corneal spherical power and astigmatism. Ophthalmology 2000;107(8):1568-71. 